\title{
Southern Hybridization of Radiolabeled Probes to Nucleic Acids Immobilized on Membranes
}

\author{
Michael R. Green and Joseph Sambrook
}

In this protocol, restriction fragments that have been transferred to a membrane by Southern blotting are hybridized to a labeled probe. Methods for stripping the probe from the membrane are also included.

It is essential that you consult the appropriate Material Safety Data Sheets and your institution's Environmental Health and Safety Office for proper handling of equipment and hazardous materials used in this protocol.

RECIPES: Please see the end of this protocol for recipes indicated by $<R>$. Additional recipes can be found online at http://cshprotocols.cshlp.org/site/recipes.

DNA immobilized on membrane (see Protocol: Southern Blotting [Green and Sambrook 2021a]) For a discussion of Southern blotting, see Introduction: Analysis of DNA by Southern Blotting (Green and Sambrook 2021b).

Formamide (50\%), $2 \times$ SSPE (optional; see Step 16)

$\mathrm{HCl}(3 \mathrm{~N}$; optional; see Step 3)

$\mathrm{NaOH}$ (0.4 м; optional; see Step 16)

$\mathrm{NaOH}$ (3 N; optional; see Step 3)

Phosphate-SDS washing solution $1<\mathrm{R}>$

Phosphate-SDS washing solution $2<\mathrm{R}>$

Prehybridization/hybridization solutions (see below)

Prepare the prehybridization solution appropriate for the task at hand. Approximately $0.2 \mathrm{~mL}$ of prehybridization solution is required for each square centimeter of membrane. Smaller volumes $\left(\sim 0.1 \mathrm{~mL} / \mathrm{cm}^{2}\right)$ can be used when hybridizing in roller bottles.

Prehybridization/hybridization solution may be prepared with or without poly $(A)$ RNA. When ${ }^{32}$ P-labeled cDNA or RNA is used as a probe, poly (A) RNA may be included in prehybridization or hybridization solutions to prevent the probe from binding to thymidine-rich sequences commonly found in eukaryotic DNA. Poly(A) RNA should be added to aqueous and formamide hybridization buffers at a final concentration of $1 \mu \mathrm{g} / \mathrm{mL}$.

Prehybridization/hybridization solution for hybridization in aqueous buffer $<\mathrm{R}>$

This is the standard buffer that has been used in Southern hybridizations for over 40 years. The solution can be made with either SSC or SSPE; SSPE contains EDTA, which is a better chelator of divalent metal ions (e.g., $\mathrm{Mg}^{2+}$ )

From the Molecular Cloning collection, edited by Michael R. Green and Joseph Sambrook. 
than citrate, and, in turn, will more efficiently inhibit DNase activity that can decrease probe and target DNA concentrations.

After thorough mixing, filter the solution through a $0.45-\mu m$ disposable cellulose acetate membrane.

Prehybridization/hybridization solution for hybridization in formamide buffers $<\mathrm{R}>$

After thorough mixing, filter the solution through a $0.45-\mu$ m disposable cellulose acetate membrane.

See Box 1.

Prehybridization/hybridization solution for hybridization in phosphate-SDS buffer (Church buffer) $<\mathrm{R}>$

Probe DNA or RNA

For Southern analysis of mammalian genomic DNA, where each lane of the gel contains $10 \mu \mathrm{g}$ of DNA, use 10$20 \mathrm{ng} / \mathrm{mL}$ radiolabeled probe (specific activity $\geq 10^{9} \mathrm{cpm} / \mu \mathrm{g}$ ). For Southern analysis of cloned DNA fragments, where each band of the restriction digest contains $10 \mathrm{ng}$ of DNA or more, much less probe is required. When analyzing cloned DNA, hybridization is performed for 6-8 h using $1-2 \mathrm{ng} / \mathrm{mL}$ radiolabeled probe (specific activity $=10^{6}$ to $10^{9} \mathrm{cpm} / \mu \mathrm{g}$ ).

See Discussion.

SSC (0.01×; optional; see Step 14)

SSC $(0.05 \times)$ with 0.01 m EDTA (pH 8.0) (optional; see Step 11)

$\operatorname{SSC}(0.1 \times)$

SSC $(0.1 \times)$ with $0.1 \%(\mathrm{w} / \mathrm{v})$ SDS

SSC $(0.1 \times), 0.1 \%(\mathrm{w} / \mathrm{v})$ SDS, $0.2 \mathrm{~m}$ Tris-Cl (pH 7.6) (optional; see Step 16)

\section{BOX 1. FORMAMIDE AND ITS USE IN HYBRIDIZATION REACTIONS}

Formamide is used as an ionizing solvent in aqueous buffers. Many batches of high-grade formamide are sufficiently pure to be used without further treatment. However, as a rule of thumb, if any yellow color is present or if there is even the hint of a smell of ammonia, the formamide should be purified. A more rigorous test of purity is to measure conductivity, which rises as the formamide breaks down to ammonium formate. The conductivity of pure formamide is 1.7 (Casey and Davidson 1977), and the conductivity of a $10^{-3} \mathrm{M}$ solution of ammonium formate is $\sim 650 \mu$ mho. The conductivity of formamide used in reannealing experiments should be $<2.0 \mu$ mho.

Formamide can be deionized by stirring for $1 \mathrm{~h}$ on a magnetic stirrer with a mixed bed ion-exchange resin (e.g., Dowex AG8, 20-50 mesh, or G 501-X8[D]). The solution is then filtered through Whatman \#1 paper and stored in small aliquots at $-20^{\circ} \mathrm{C}$, preferably under nitrogen. Each resin can be reused several times. $\mathrm{X} 8(\mathrm{D})$ contains an indicator that changes color when the resin is exhausted.

\section{Hybridization Reactions}

Bonner et al. (1967) were the first to use formamide as a solvent in hybridization reactions. At the end of their brief paper, they wrote:

That formamide should take the place of elevated temperature in the hybridization process is to be expected. Aqueous solutions of formamide denature DNA as has been shown by Helmkamp and Ts'o (1961) and Marmur and Ts'o (1961). The concentrations of formamide required for DNA-RNA hybridization, 30-40 vol\%, are well below the $60 \mathrm{vol} \%$ found by Marmur and Ts'o to be required for denaturation of native DNA (in $0.02 \mathrm{M} \mathrm{NaCl}-0.002 \mathrm{~m}$ sodium citrate).

What has now been found by serendipity is that hybridization as conducted in aqueous formamide possesses distinct advantages over hybridization conducted at elevated temperatures. These advantages include increased retention of immobilized DNA by the nitrocellulose filters and decreased nonspecific background absorption. These two factors combine to result in an increased reproducibility of replicates with the hybridization procedure. Hybridization in formamide solution at low temperature is helpful also in minimizing scission of nucleic acid molecules during prolonged periods of incubation.

In addition to these advantages, increased flexibility is introduced into the design of reaction conditions for a given experiment. It is more convenient to control this stringency of hybridization with formamide rather than through adjustment of the incubation temperature. 
M.R. Green and J. Sambrook

SSC $(2 \times)$ with $0.1 \%(\mathrm{w} / \mathrm{v})$ SDS

SSC $(2 \times)$ with $0.5 \%(w / v)$ SDS

$\operatorname{SSC}(6 \mathrm{X})<\mathrm{R}>$ or SSPE $(6 \mathrm{X})<\mathrm{R}>$

$\operatorname{SSC}(20 \times)<\mathrm{R}>$

SSPE (0.1 $\times$; optional; see Step 16)

Tris-Cl (pH 7.2; 1 м; optional; see Step 3)

Tris-Cl (pH 8.0; 1 mm), 1 mm EDTA (pH 8.0), 0.1× Denhardt's reagent (optional; see Step 16)

Equipment

Disposable cellulose acetate membrane $(0.45-\mu \mathrm{m}$; Schleicher \& Schuell Uniflow syringe membrane or equivalent)

Heat sealer (if using heat-sealable bag)

Hybridization container (heat-sealable bag, roller bottle, or plastic container)

Incubator or commercial hybridization device preset to the appropriate temperature

Incubator or shaking water bath preset to $65^{\circ} \mathrm{C}$ (for hybridization in phosphate-SDS buffer)

Paper towels

Phosphorescent adhesive dots

Phosphorimager

Plastic wrap (e.g., Saran Wrap)

Radioactivity minimonitor

Rocking/rotating platform

Tray for soaking membrane

Water bath

X-ray film (optional; see Steps 14 and 17)

METHOD

Southern Hybridization

1. Float the membrane containing the target DNA on the surface of a tray of $6 \times$ SSC (or $6 \times$ SSPE) until the membrane becomes thoroughly wetted from beneath. Submerge the membrane for 2 min.

2. Prehybridize the membrane by one of the following methods.

\section{For Hybridization in a Heat-Sealable Bag}

i. Slip the wet membrane into a heat-sealable bag (e.g., Sears Seal-A-Meal or equivalent), and add $0.2 \mathrm{~mL}$ of prehybridization solution for each square centimeter of membrane. Squeeze as much air as possible from the bag.

ii. Seal the open end of the bag with a heat sealer, and then make a second seal. Test the strength and integrity of the seal by gently squeezing the bag. Incubate the bag for $1-2 \mathrm{~h}$ submerged in a water bath set to the appropriate temperature $\left(68^{\circ} \mathrm{C}\right.$ for aqueous solvents; $42^{\circ} \mathrm{C}$ for solvents containing $50 \%$ formamide; $65^{\circ} \mathrm{C}$ for phosphate-SDS solvents).

\section{For Hybridization in a Roller Bottle}

i. Gently roll the wetted membrane into the shape of a cylinder, and place it inside a hybridization roller bottle together with the plastic mesh provided by the manufacturer. Add $0.1 \mathrm{~mL}$ of prehybridization solution for each square centimeter of membrane. Close the bottle tightly. 
ii. Place the hybridization tube inside a prewarmed hybridization oven at the appropriate temperature $\left(68^{\circ} \mathrm{C}\right.$ for aqueous solvents; $42^{\circ} \mathrm{C}$ for solvents containing $50 \%$ formamide; $65^{\circ} \mathrm{C}$ for phosphate-SDS solvents).

\section{For Hybridization in a Plastic Container}

i. Place the wetted membrane in a plastic (e.g., Tupperware) container, and add $0.2 \mathrm{~mL}$ of prehybridization solution for each square centimeter of membrane.

ii. Seal the box with the lid, and place the box on a rocking platform in an air incubator set at the appropriate temperature $\left(68^{\circ} \mathrm{C}\right.$ for aqueous solvents; $42^{\circ} \mathrm{C}$ for solvents containing $50 \%$ formamide; $65^{\circ} \mathrm{C}$ for phosphate-SDS solvents).

3. If the radiolabeled probe is double-stranded DNA, denature it by heating for $5 \mathrm{~min}$ at $100^{\circ} \mathrm{C}$. Chill the probe rapidly in ice water.

Alternatively, denature DNA probes by adding 0.1 volume of $3 \mathrm{~N} \mathrm{NaOH}$. After 5 min at room temperature, chill the probe to $0^{\circ} \mathrm{C}$ in an ice-water bath, and add 0.05 volume of $1 \mathrm{M} \mathrm{Tris-Cl}(\mathrm{pH} \mathrm{7.2)}$ ) and 0.1 volume of $3 \mathrm{~N} \mathrm{HCl}$. Store the probe in ice water until it is needed.

Single-stranded DNA and RNA probes need not be denatured.

4. To hybridize the probe to a blot containing genomic DNA, perform one of the following methods.

\section{For Hybridization in a Heat-Sealable Bag}

i. Working quickly, remove the bag containing the membrane from the water bath. Open the bag by cutting off one corner with scissors, and pour off the prehybridization solution.

ii. Add the denatured probe to an appropriate amount of fresh prehybridization solution, and deliver the solution into the bag. Squeeze as much air as possible from the bag.

iii. Reseal the bag with the heat sealer; make sure that as few bubbles as possible are trapped in the bag. To avoid radioactive contamination of the water bath, seal the resealed bag inside a second, noncontaminated bag. Incubate the bag submerged in a water bath set at the appropriate temperature for the required period of hybridization.

\section{For Hybridization in a Roller Bottle}

i. Pour off the prehybridization solution from the hybridization bottle, and replace it with fresh hybridization solution containing probe.

ii. Seal the bottle and replace it in the hybridization oven. Incubate for the required period of hybridization.

\section{For Hybridization in a Plastic Container}

i. Transfer the membrane from the container to a sealable bag or a hybridization bottle.

ii. Immediately treat it as described above.

5. After hybridization, wash the membrane.

When hybridizing in phosphate-SDS solution, remove the membrane from the hybridization chamber as described in Step 5, and place it in several hundred milliliters (i.e., $\sim 1 \mathrm{~mL} / \mathrm{cm}^{2}$ membrane) of PhosphateSDS washing solution 1 at $65^{\circ} \mathrm{C}$. Agitate the tray. Repeat this rinse once.

Do not allow the membrane to dry out at any stage during the washing procedure.

\section{For Hybridization in a Heat-Sealable Bag}

i. Wearing gloves, remove the bag from the water bath, remove the outer bag, and immediately cut off one corner of the inner bag. Pour out the hybridization solution into a 
M.R. Green and J. Sambrook

container suitable for disposal of radioactivity, and then cut the bag along the length of three sides.

ii. Remove the membrane and immediately submerge it in a tray containing several hundred milliliters of $2 \times$ SSC and $0.5 \%$ SDS (i.e., $\sim 1 \mathrm{~mL} / \mathrm{cm}^{2}$ membrane) at room temperature. Agitate the tray gently on a slowly rotating platform.

\section{For Hybridization in a Roller Bottle}

i. Remove the membrane from the hybridization bottle, and briefly drain excess hybridization solution from the membrane by holding the corner of the membrane to the lip of the bottle or container.

ii. Place the membrane in a tray containing several hundred milliliters of $2 \times$ SSC and $0.5 \%$ SDS (i.e., $\sim 1 \mathrm{~mL} / \mathrm{cm}^{2}$ membrane) at room temperature. Agitate the tray gently on a slowly rotating platform.

6. After $5 \mathrm{~min}$, pour off the first rinse solution into a radioactivity disposal container, and add several hundred milliliters of $2 \times$ SSC and $0.1 \%$ SDS to the tray. Incubate for $15 \mathrm{~min}$ at room temperature with occasional gentle agitation.

If hybridization was performed in a phosphate-SDS buffer, rinse the membrane a total of eight times for 5 min each in several hundred milliliters of Phosphate-SDS washing solution 2 at $65^{\circ} \mathrm{C}$. Skip to Step 9 after the eighth rinse.

7. Replace the rinse solution with several hundred milliliters of fresh $0.1 \times$ SSC with $0.1 \%$ SDS. Incubate the membrane for $30 \mathrm{~min}$ to $4 \mathrm{~h}$ at $65^{\circ} \mathrm{C}$ with gentle agitation.

During the washing step, periodically monitor the amount of radioactivity on the membrane using a handheld minimonitor. The parts of the membrane that do not contain DNA should not emit a detectable signal. Do not expect to pick up a signal on the minimonitor from membranes containing mammalian DNA that has been hybridized to single-copy probes.

8. Briefly wash the membrane with $0.1 \times$ SSC at room temperature.

9. Remove most of the liquid from the membrane by placing it on a pad of paper towels. Place the damp membrane on a sheet of Saran Wrap. Apply adhesive dot labels marked with phosphorescent dots to several asymmetrically placed locations on the Saran Wrap. These markers serve to align the autoradiograph with the membrane.

Alternatively, dry the membrane in the air, and glue it to a piece of 3MM paper using a water-soluble glue.

10. Cover the membrane with a sheet of Saran Wrap, and expose the membrane to a phosphorimager plate. An exposure time of $1-4 \mathrm{~h}$ is usually long enough to detect single-copy gene sequences in a Southern blot of mammalian genomic DNA.

If the DNA on the membrane is to be hybridized with a different probe, proceed to Step 11.

Several factors can cause unwanted background in Southern hybridizations. Table 1 outlines the most common symptoms and prophylactic measures to reduce background.

Stripping Probes from Membranes

Although in many cases it is possible to remove probes from membranes after an image has been recorded and to reprobe the membrane with different probes, the following are some of the problems associated with this procedure.

- Irreversible binding of the probe to the membrane. Probes become irreversibly bound when nitrocellulose membranes and nylon membranes are allowed to dry for extended periods of time. If a given membrane is to be hybridized with more than one probe, every effort should be made to ensure that the solid support remains wet at all stages during hybridization, washing, and exposure to X-ray film or phosphorimager cassettes.

- Fragility of membranes. Nylon membranes containing either genomic DNA or RNA can be stripped and rehybridized five to 10 times. Nitrocellulose membranes, however, are more fragile and generally do not survive more than two or three cycles of hybridization and stripping. 


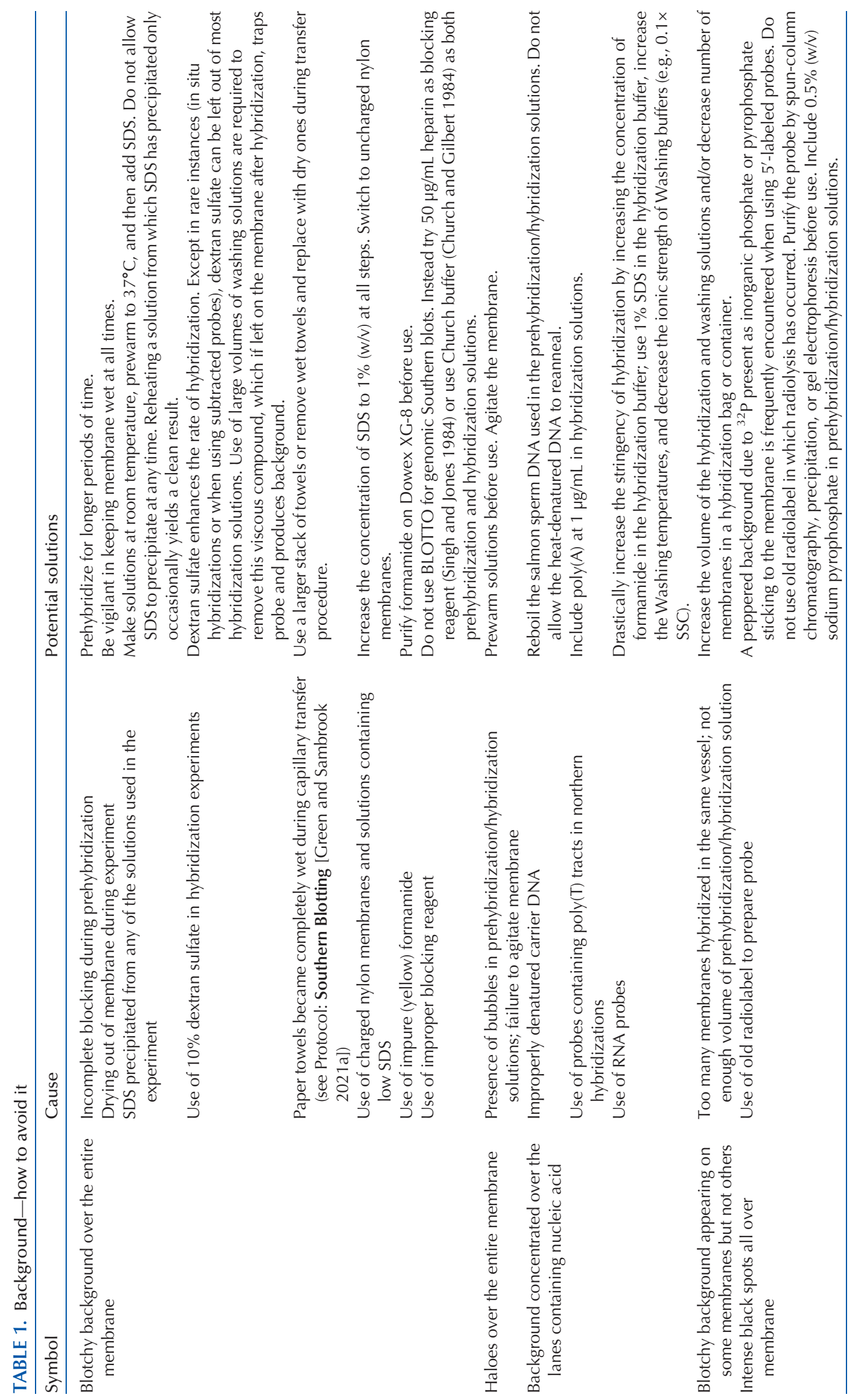


M.R. Green and J. Sambrook

TABLE 2. Solutions for removing hybridized probe from a nylon membrane

\begin{tabular}{|c|c|c|}
\hline Stripping solution & Treatment & Washing solution \\
\hline $\begin{array}{l}1 \text { mм Tris-Cl }(\mathrm{pH} 8.0), 1 \text { mм EDTA ( } \mathrm{pH} 8.0), 0.1 \times \\
\text { Denhardt's reagent }\end{array}$ & $2 \mathrm{~h}$ at $75^{\circ} \mathrm{C}$ & $0.1 \times \mathrm{SSPE}$ at room temperature \\
\hline $50 \%$ formamide, $2 \times$ SSPE & $1 \mathrm{~h}$ at $65^{\circ} \mathrm{C}$ & $0.1 \times$ SSPE at room temperature \\
\hline $0.4 \mathrm{M} \mathrm{NaOH}$ & $30 \mathrm{~min}$ at $42^{\circ} \mathrm{C}$ & $\begin{array}{l}0.1 \times \mathrm{SSC}, 0.1 \% \mathrm{SDS}, 0.2 \mathrm{M} \text { Tris- } \mathrm{Cl}(\mathrm{pH} 7.6) \text { for } 30 \\
\quad \min \text { at } 42^{\circ} \mathrm{C}\end{array}$ \\
\hline
\end{tabular}

- Leaching of nucleic acids from the membranes. A fraction of the DNA or RNA immobilized on the membrane leaches away during each cycle of hybridization and stripping so that the strength of the signal decreases progressively with each use. Nitrocellulose membranes are the worst offenders in this respect.

\section{Method 1: Elution of Probe from the Membrane}

11. Prepare elution buffer by heating several hundred milliliters of $0.05 \times$ SSC, $0.01 \mathrm{~m}$ EDTA ( $\mathrm{pH} 8.0$ ) to boiling. Remove the fluid from the heat, and add SDS to a final concentration of $0.1 \%(\mathrm{w} / \mathrm{v})$.

12. Immerse the membrane in the hot elution buffer for $15 \mathrm{~min}$. Rock or rotate the container during this time period.

13. Repeat Step 12 with a fresh batch of boiling elution buffer.

Do not allow the membrane to dry when transferring it between batches of hot elution buffer.

14. Rinse the membrane briefly in $0.01 \times$ SSC at room temperature. Blot most of the liquid from the membrane by placing it on a pad of paper towels, sandwich the damp membrane between two sheets of Saran Wrap, and apply it to X-ray film to check that all of the probes have been removed.

15. Dry the membrane, wrap it loosely in aluminum foil or between sheets of blotting paper, and store it at room temperature-preferably under vacuum — until needed. To rehybridize the membrane, place it in prehybridization solution, and continue with Step 2 above.

\section{Method 2: Removal of a Hybridized Probe from a Charged or Neutral Nylon Membrane}

Most manufacturers of nylon membranes provide instructions describing how various types of probes may best be stripped from their particular type of membrane. It is advisable to follow these instructions. Alternatively, treat the hybridized membrane with one of the three stripping solutions as described in Table 2.

16. Prepare several hundred milliliters of one of the recipes for stripping solution given in Table 2, immerse the membrane, and treat as described to remove the probe and to wash the membrane.

17. Blot most of the liquid from the membrane by placing it on a pad of paper towels, sandwich the damp membrane between two sheets of Saran Wrap, and apply it to X-ray film to ensure that all of the probes have been removed.

18. Dry the membrane, wrap it loosely in aluminum foil or between sheets of blotting paper, and store it at room temperature-preferably under vacuum-until needed. To rehybridize the membrane, place it in prehybridization solution, and continue with Step 2 above.

The goal of Southern hybridization is to detect a target DNA sequence in a mixture of DNA fragments. Success with the method depends on the availability of a probe whose sequence is unique to and specific for the target. Finding a probe with these properties is straightforward when the complexity of the starting DNA is low, repetitive elements are few in number, and the nucleotide sequence of the 
target is unique. In such cases, manual methods can be used to select suitable probes. However, when the genetic complexity of the starting DNA is large and/or its sequence is complex-as is the case, for example, with mammalian genomic DNA-it is best to use a genome browser to select a target sequence. A BLAST tool is used to search the starting genome and to identify a sequence unique to the target with no significant homology with other loci of the starting DNA. Perseverance is sometimes required to identify probes with no ability to cross-hybridize to homologous DNA sequences that may be present in the starting DNA. An alternative method is to use a bioinformatics pipeline to automatically design probes with high discriminating power that are predicted to perform better than those identified manually (see, e.g., Croning et al. 2010).

The strength of the signal obtained in Southern hybridizations depends on several factors, including the proportion of immobilized DNA that is complementary to the probe, the size of the probe and its specific activity, and the amount of genomic DNA transferred to the membrane. Under the best conditions, the method is sufficiently sensitive to detect $<0.1 \mathrm{pg}$ of DNA complementary to a probe that has been radiolabeled with ${ }^{32} \mathrm{P}$ to high specific activity $\left(>10^{9} \mathrm{cpm} / \mu \mathrm{g}\right)$. A sequence of $1000 \mathrm{bp}$ that occurs only once in the mammalian genome (i.e., 1 part in 3 million) can be detected in an overnight exposure to conventional X-ray film (or 15-60 min on a phosphorimager) if $10 \mu \mathrm{g}$ of genomic DNA is transferred to the membrane and hybridized to a probe several hundred nucleotides in length. Because the strength of the signal is proportional to the specific activity of the probe and inversely proportional to its length, Southern hybridization reaches the limits of its sensitivity when very short probes are used. To obtain a signal from single-copy genomic sequences with, for example, oligonucleotide probes, it is necessary to radiolabel to the highest specific activity possible, to increase the amount of target DNA on the membrane, and to expose the autoradiograph for several days or the phosphorimager plate for many hours.

\section{Hybridization at Low Stringency}

The detection of genes that are related but not identical in sequence to a particular probe can sometimes be accomplished by hybridizing under conditions of reduced stringency. Success depends chiefly on (1) the degree of sequence identity between the hybridization probe and the target and (2) the judicious choice of hybridization conditions. Members of a gene family from single species or orthologous genes from different species can almost always be isolated by lowstringency hybridization if they share $65 \%$ or greater sequence identity. The identification of genes that share $<65 \%$ identity requires skill in the art and sometimes luck. Genes in the latter category are more frequently isolated by low-stringency polymerase chain reaction (PCR). The following hybridization/washing conditions can be used to identify genes that share $\geq 65 \%$ sequence identity.

- For Southern hybridization or screening of bacteriophage plaques and bacterial colonies, set up hybridization reactions in a buffer containing $30 \%$ (v/v) deionized formamide, $0.6 \mathrm{M} \mathrm{NaCl}, 0.04 \mathrm{M}$ sodium phosphate ( $\mathrm{pH} 7.4$ ), $2.5 \mathrm{~mm}$ EDTA ( $\mathrm{pH}$ 8.0), 1\% SDS, and radiolabeled denatured probe $\left(1 \times 10^{6}\right.$ to $2 \times 10^{6} \mathrm{cpm} / \mathrm{mL}$ of hybridization solution). Hybridize for $16 \mathrm{~h}$ at $42^{\circ} \mathrm{C}$.

- For northern hybridizations, hybridize in $50 \%$ deionized formamide, $0.25 \mathrm{M} \mathrm{NaCl}, 0.10 \mathrm{M}$ sodium phosphate ( $\mathrm{pH} 7.2), 2.5 \mathrm{~mm}$ EDTA ( $\mathrm{pH} 8.0), 7 \%$ SDS, and radiolabeled denatured probe $\left(1 \times 10^{6}\right.$ to $2 \times 10^{6} \mathrm{cpm} / \mathrm{mL}$ of hybridization solution). Hybridize for $16 \mathrm{~h}$ at $42^{\circ} \mathrm{C}$.

At the end of the hybridization reaction, wash the membranes twice with $2 \times$ SSC $/ 0.1 \%$ SDS for 10 min each at room temperature, followed by a wash for $1 \mathrm{~h}$ at $55^{\circ} \mathrm{C}$ in $2 \times \mathrm{SSC} / 0.1 \% \mathrm{SDS}$. Use large volumes of rinse and wash solutions; make sure that they are at the appropriate temperature before use. The identification of genes that share $<65 \%$ sequence is trickier but may be accomplished by using one or more of the following approaches.

- Use an RNA probe prepared by in vitro transcription. The increased stability of RNA-DNA hybrids over DNA-DNA hybrids (Casey and Davidson 1977; Zuker et al. 1985) can sometimes make the difference between seeing a signal and not seeing a signal. However, RNA probes may 
M.R. Green and J. Sambrook

generate high backgrounds that are difficult to remove with low-stringency washes. The use of uncharged nylon membranes may alleviate this problem.

- Decrease the formamide concentration to $20 \%$ and hybridize at $34^{\circ} \mathrm{C}$. Rinse and wash the hybridized membranes as described above.

- Use a commercial "rapid hybridization" solution (see the Rapid Hybridization Buffers section below), and wash the membranes according to the manufacturer's instructions.

\section{Rapid Hybridization Buffers}

Several cationic detergents dramatically enhance the rate of hybridization of two complementary strands of nucleic acid (Pontius and Berg 1991). These include dodecyltrimethylammonium bromide (DTAB) and cetyltrimethylammonium bromide (CTAB), which are variants of the quaternary amine tetramethylammonium bromide. The latter compound is used to stabilize duplexes formed between oligonucleotide probes and target sequences. At concentrations in the millimolar range, $\mathrm{DTAB}$ and $\mathrm{CTAB}$ enhance the rate of renaturation of two complementary strands of DNA $>10,000$-fold. The increase in hybridization rate is specific and occurs in the presence of as much as a $10^{6}$-fold excess of noncomplementary DNAs.

Several commercial manufacturers now sell rapid hybridization solutions that decrease the required hybridization time from $16 \mathrm{~h}$ to $1-2 \mathrm{~h}$. Although the chemical composition of these premade solutions is a trade secret, it seems likely that some of them contain quaternary ammonium compounds, whereas others contain volume excluders such as 10\% dextran sulfate (Wahl et al. 1979; Renz and Kurz 1984; Amasino 1986) or 5\% PEG 35,000 (Kroczek 1993). Hybridization times can be reduced by a factor of 5 or more if these rapid hybridization solutions are used instead of conventional hybridization buffers. In addition, these hybridization accelerators improve the efficiency of hybridization when low concentrations of probe are used $(\sim 1 \mathrm{ng} / \mathrm{mL})$. The rapid hybridization solution should be preheated to the correct hybridization temperature before it is added to the membranes. Radiolabeled probes should be added to preheated rapid hybridization solution before adding it to the membrane.

In our experience, rapid hybridization buffers work extremely well for Southern hybridization. However, when hybridization accelerators are used in northern hybridization, the background of hybridization to ribosomal RNAs increases greatly-sometimes to levels that are unacceptable.

Phosphate-SDS Washing Solution 1

40 mM sodium phosphate buffer ( $\mathrm{pH} 7.2)$

$5 \%(\mathrm{w} / \mathrm{v})$ SDS

$0.5 \%(\mathrm{w} / \mathrm{v})$ Fraction-V-grade bovine serum albumin

1 mм EDTA (pH 8.0)

Phosphate-SDS Washing Solution 2

1 mм EDTA (pH 8.0)

$1 \%(\mathrm{w} / \mathrm{v})$ SDS

$40 \mathrm{~mm}$ sodium phosphate buffer ( $\mathrm{pH} 7.2)$

Prehybridization/Hybridization Solution for Hybridization in Aqueous Buffer

$5 \times$ Denhardt's reagent

$1 \mu \mathrm{g} / \mathrm{mL} \operatorname{poly}(\mathrm{A})$

$100 \mu \mathrm{g} / \mathrm{mL}$ salmon sperm DNA

$0.5 \%(\mathrm{w} / \mathrm{v})$ SDS

$6 \times$ SSC (or $6 \times$ SSPE) 


\title{
Prehybridization/Hybridization Solution for Hybridization in Formamide Buffers
}

\author{
$5 \times$ Denhardt's reagent \\ $50 \%(\mathrm{v} / \mathrm{v})$ formamide \\ $0.5 \%(\mathrm{w} / \mathrm{v})$ SDS \\ $100 \mu \mathrm{g} / \mathrm{mL}$ salmon sperm DNA \\ $1 \mu \mathrm{g} / \mathrm{mL} \operatorname{poly}(\mathrm{A})$ \\ $6 \times$ SSC (or $6 \times$ SSPE)
}

After a thorough mixing, filter the solution through a $0.45-\mu \mathrm{m}$ disposable cellulose acetate membrane (Schleicher \& Schuell Uniflow syringe membrane or equivalent). To decrease background when hybridizing under conditions of reduced stringency (e.g., 20\%-30\% formamide), it is important to use formamide that is as pure as possible.

\section{Prehybridization/Hybridization Solution for Hybridization in Phosphate-SDS Buffer}

$0.5 \mathrm{M}$ phosphate buffer $(\mathrm{pH} 7.2)^{\star}$

1 mм EDTA (pH 8.0)

$1 \%(\mathrm{w} / \mathrm{v})$ bovine serum albumin

$7 \%(\mathrm{w} / \mathrm{v})$ SDS

Use an electrophoresis grade of bovine serum albumin. No blocking agents or hybridization rate enhancers are required with this particular prehybridization/hybridization solution.

${ }^{\star} 0.5 \mathrm{M}$ phosphate buffer is $134 \mathrm{~g}$ of $\mathrm{Na}_{2} \mathrm{HPO}_{4} \cdot 7 \mathrm{H}_{2} \mathrm{O}, 4 \mathrm{~mL}$ of $85 \% \mathrm{H}_{3} \mathrm{PO}_{4}$ (concentrated phosphoric acid), $\mathrm{H}_{2} \mathrm{O}$ to 1 liter.

\section{SSC}

For a $20 \times$ solution: Dissolve $175.3 \mathrm{~g}$ of $\mathrm{NaCl}$ and $88.2 \mathrm{~g}$ of sodium citrate in $800 \mathrm{~mL}$ of $\mathrm{H}_{2} \mathrm{O}$. Adjust the $\mathrm{pH}$ to 7.0 with a few drops of a $14 \mathrm{~N}$ solution of $\mathrm{HCl}$. Adjust the volume to $1 \mathrm{~L}$ with $\mathrm{H}_{2} \mathrm{O}$. Dispense into aliquots. Sterilize by autoclaving. The final concentrations of the ingredients are $3.0 \mathrm{M} \mathrm{NaCl}$ and $0.3 \mathrm{~m}$ sodium citrate.

\section{SSPE}

For $20 \times$ solution: Dissolve $175.3 \mathrm{~g}$ of $\mathrm{NaCl}, 27.6 \mathrm{~g}$ of $\mathrm{NaH}_{2} \mathrm{PO}_{4} \cdot \mathrm{H}_{2} \mathrm{O}$, and $7.4 \mathrm{~g}$ of EDTA in $800 \mathrm{~mL}$ of $\mathrm{H}_{2} \mathrm{O}$. Adjust the $\mathrm{pH}$ to 7.4 with $\mathrm{NaOH}(\sim 6.5 \mathrm{~mL}$ of a $10 \mathrm{~N}$ solution). Adjust the volume to $1 \mathrm{~L}$ with $\mathrm{H}_{2} \mathrm{O}$. Dispense into aliquots. Sterilize by autoclaving. The final concentrations of the ingredients are $3.0 \mathrm{M} \mathrm{NaCl}, 0.2 \mathrm{M} \mathrm{NaH}_{2} \mathrm{PO}_{4}$, and $0.02 \mathrm{M}$ EDTA.

\section{REFERENCES}

Amasino RM. 1986. Acceleration of nucleic acid hybridization rate by polyethylene glycol. Anal Biochem 152: 304-307.

Bonner J, Kung G, Bekhor I. 1967. A method for the hybridization of nucleic acid molecules at low temperature. Biochemistry 6: 36503653.

Casey J, Davidson N. 1977. Rates of formation and thermal stabilities of RNA:DNA and DNA:DNA duplexes at high concentrations of formamide. Nucleic Acids Res 4: 1539-1552.

Church GM, Gilbert W. 1984. Genomic sequencing. Proc Natl Acad Sci 81: 1991-1995.

Croning MD, Fricker DG, Komiyama NH, Grant SG. 2010. Automated design of genomic Southern blot probes. BMC Genomics 11: 74.

Green MR, Sambrook J. 2021a. Southern blotting. Cold Spring Harb Protoc doi:10.1101/pdb.prot100487.

Green MR, Sambrook J. 2021b. Analysis of DNA by Southern blotting. Cold Spring Harb Protoc doi:10.1101/pdb.top100396.

Helmkamp G, Ts'o POP. 1961. The secondary structures of nucleic acids in organic solvents. J Am Chem Soc 83: 138-142.
Kroczek RA. 1993. Southern and northern analysis. J Chromatogr 618: 133-145.

Marmur J, Ts'o POP. 1961. Denaturation of deoxyribonucleic acid by formamide. Biochim Biophys Acta 51: 32-36.

Pontius BW, Berg P. 1991. Rapid renaturation of complementary DNA strands mediated by cationic detergents: A role for high-probability binding domains in enhancing the kinetics of molecular assembly processes. Proc Natl Acad Sci 88: 8237-8241.

Renz M, Kurz C. 1984. A colorimetric method for DNA hybridization. Nucleic Acids Res 12: 3435-3444.

Singh L, Jones KW. 1984. The use of heparin as a simple cost-effective means of controlling background in nucleic acid hybridization procedures. Nucleic Acids Res 12: 5627-5638.

Wahl GM, Stern M, Stark GR. 1979. Efficient transfer of large DNA fragments from agarose gels to diazobenzyloxymethyl-paper and rapid hybridization by using dextran sulfate. Proc Natl Acad Sci 76: 3683-3687.

Zuker CS, Cowman AF, Rubin GM. 1985. Isolation and structure of a rhodopsin gene from D. melanogaster. Cell 40: 851-858. 


\section{Southern Hybridization of Radiolabeled Probes to Nucleic Acids Immobilized on Membranes}

Michael R. Green and Joseph Sambrook

Cold Spring Harb Protoc; doi: 10.1101/pdb.prot100495

\begin{tabular}{|c|c|}
\hline $\begin{array}{l}\text { Email Alerting } \\
\text { Service }\end{array}$ & Receive free email alerts when new articles cite this article - click here. \\
\hline $\begin{array}{l}\text { Subject } \\
\text { Categories }\end{array}$ & $\begin{array}{l}\text { Browse articles on similar topics from Cold Spring Harbor Protocols. } \\
\text { Bioinformatics/Genomics, general (192 articles) } \\
\text { Blots ( } 66 \text { articles) } \\
\text { Genome Analysis (191 articles) } \\
\text { Genomic DNA (135 articles) } \\
\text { Molecular Biology, general (1293 articles) } \\
\text { Probes (92 articles) } \\
\text { Probes, general (72 articles) } \\
\text { Radiolabeled Probes (54 articles) }\end{array}$ \\
\hline
\end{tabular}

